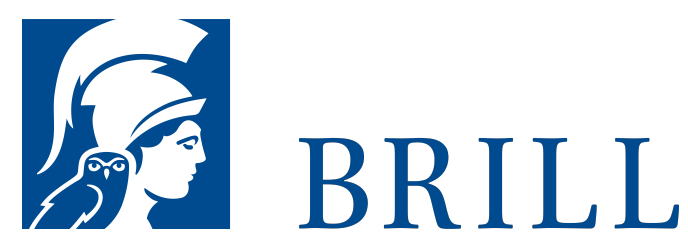

\title{
The Wisconsin Papyri
}

Part I

Author: Sijpesteijn

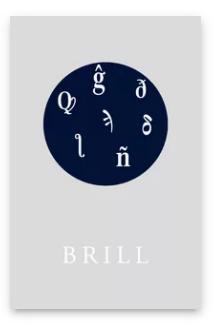

Pages: $\mathrm{x},{ }^{151} \mathrm{pp}$. 37 facs. on 14 plates

Language:

English

Subjects:

General,

Classical Studies

Publisher: Brill

Series:

Papyrologica

Lugduno-Batava

E-Book (PDF)

Released online:

O2 Mar $202 \mathrm{O}$

ISBN: $978-90-$

04-42768-6

List price

USD \$121.00

Paperback

Publication date: o1 Dec 1967

ISBN: 978-90-

04-01701-6 
For more information see brill.com

Order information: Order online at brill.com +44330 333 0049 | customerservices@brill.com Submission information: brill.com/authors

Titles published by Brill | Fink, Brill | mentis or Brill | Schöningh: +49(o)715413279216| brill@brocom.de 